\title{
Особливості мотиваційного та психічного станів жінок другого періоду зрілого віку з надлишковою масою тіла
}

\author{
Анастасія Нагорна, Олена Андрєєва, \\ Ксенія Левінська
}

Національний університет фрізичного виховання і спорту України, Київ, Україна

\begin{abstract}
Анотація. В статті розглянуто особливості мотивації, якості життя, психічного стану жінок другого періоду зрілого віку з надлишковою масою тіла та ожирінням, визначено провідні мотиви до занять руховою активністю з використанням засобів фітнесу. Мета. Вивчити особливості мотиваційного та психічного станів жінок другого періоду зрілого віку з надлишковою масою тіла як основи побудови самостійних профілактично-оздоровчих занять. Методи. Теоретичний аналіз та узагальнення сучасних даних наукової, методичної та спеціальної літератури, соціологічні, педагогічні, психодіагностичні методи дослідження, методи математичної статистики. Результати. Визначено, що пріоритетними мотивами групи жінок, які взяли участь у дослідженні, є: оздоровлення (71,8 \%), естетичні $(69,5 \%)$ та особистісні мотиви $(49,5 \%)$. Результати досліджень вказують на те, що середньогруповий показник індексу якості життя у жінок другого періоду зрілого віку відповідає середньому рівню і становить 25,7 бала. Аналіз індивідуальних результатів дав змогу виявити 17,1 \% жінок 3 низьким та 20,0 \% 3 високим індексом якості життя. Аналіз індивідуальних результатів, отриманих у ході тестування психічних станів жінок, вказують на низький та середній рівні тривожності, фррустрації, агресивності та ригідності. Отримані результати дали змогу виділити проблемні сфери життєдіяльності у жінок другого періоду зрілого віку з надлишковою масою тіла та встановити чинники, які викликають дискомфорт та незадоволеність якістю життя. Результати дослідження особливостей психічних санів у жінок другого періоду зрілого віку з надлишковою масою тіла вказують на відсутність високого рівня тривожності, фрустрації, агресивності та ригідності. Зазначені особливості покладено в основу розробки програми самостійних занять оздоровчим фітнесом з використанням інформаційних технологій.

Ключові слова: психічний стан, мотивація, надлишкова маса тіла, якість життя,

профрілактично-оздоровчі заняття, рухова активність, жінки, зрілий вік.
\end{abstract}

\section{Anastasia Nahorna, Olena Andreieva, Ksenia Levinska}

\section{PECULIARITIES OF MOTIVATIONAL AND MENTAL STATE OF OVERWEIGHT WOMEN OF THE SECOND PERIOD OF MATURE AGE}

Abstract. The article addresses the peculiarities of motivation, quality of life, mental state of women of the second period of mature age with overweight and obesity, identifies the leading motives for physical activity using fitness means. Objective. To study the features of motivational and mental states of overweight women of the second period of mature age as a basis for designing independent preventive and health-related classes. Methods. Theoretical analysis and generalization of modern data of scientific, methodical and special literature, sociological, pedagogical,

psychodiagnostic research methods, methods of mathematical statistics. Results. It was determined that the priority motives of the group of women who participated in the study are: health improvement $(71.8 \%)$, aesthetic $(69.5 \%)$ and personal motives $(49.5 \%)$. The findings indicate that the average group index of life quality in women of the second period of mature age corresponds to the average level and constitutes 25.7 points. The analysis of individual results revealed $17.1 \%$ of women with a low and $20.0 \%$ with a high quality of life index. Analysis of individual results obtained during testing of women's mental states indicates low and average levels of anxiety, frustration, aggression and rigidity. The obtained results allowed identifying problematic areas of vital functions in overweight women of the second period of mature age and factors that cause discomfort and dissatisfaction with quality of life. The results of examining the peculiarities of mental states in overweight women of the second period of mature age indicate the absence of high levels of anxiety, frustration, aggression and rigidity. These peculiarities were taken as the basis for the development of a program of independent health fitness classes using information technology.

Keywords: mental state, motivation, overweight, quality of life, preventive and health related classes, motor activity, women, mature age.

Nahorna A, Andreieva 0, Levinska K. Peculiarities of motivational and mental state of overweight women of the second period of mature age. Theory and Methods of Physical education and sports. 2020; 3: 86-90 DOI: 10.32652/tmfvs.2020.3.86-90
Особливості мотиваційного та психічного станів жінок другого періоду зрілого віку 3 надлишковою масою тіла. Теорія і методика фрізичного виховання і спорту. 2020; 3: 86-90

DOI: 10.32652/tmfvs.2020.3.86-90
Постановка проблеми. Вивчення мотиваційного та психічного станів жінок другого періоду зрілого віку 3 надлишковою масою тіла лежить в площині забезпечення дотримання соціально-педагогічних принципів фізичного виховання, а саме - врахування пріоритетів потреб, мотивів та інтересів особистості $[1,11]$. Такий підхід забезпечує відповідність спроєктованих профілактично-оздоровчих програм занять 3 використанням інформаційних технологій сучасному запиту жінок другого періоду зрілого віку.

Встановлено, що після 35 років через зниження рухової активності у жінок зростає маса тіла. Науковці відмічають, що у 36-45 років спостерігаються ознаки напруження адаптаційних механізмів функціональних систем [6]. 46-55 років характеризуються значними гормональними перебудовами в організмі жінки, які на фроні зниження загального морфофрункціонального статусу нерідко призводять до зриву адаптаційних процесів та стійкого погіршення здоров'я [5]. Після 45 років відбувається значне погіршення результативності виконання рухових тестів, моторики, показників здатності утримання динамічної рівноваги, рухливості поперекового відділу хребта. Кожне наступне п'ятиріччя життя характеризується зростанням кількості осіб з напруженням і зривом адаптації серцево-судинної системи. Існують дослідження, які вказують, що в діапазоні 50-55 років жінки з нормальною адаптацією серцево-судинної системи - скоріше виняток із правила, ніж норма [9].

Поряд 3 цим інтерес до самостійних занять фізичними вправами серед жінок з віком зростає через накопичення надлишкової маси тіла та відчутних наслідків інволюційних процесів. Самостійні фізкультурнооздоровчі заняття виділяються науковцями як один із найбільш прива- 
блюючих видів рухової активності для жінок $36-55$ років $[2,3,13,15]$. Проєктування самостійних фрізкультурнооздоровчих занять з використанням інформаційних технологій, які б враховували особливості мотиваційного та психічного станів жінок другого періоду зрілого віку, покликані забезпечити комфортність, яку деякі спеціалісти відносять до обов'язкової вимоги під час надання фітнес-послуг, наголошуючи, що саме комфортність $€$ принциповою відмінністю фрітнесу від інших сорер [7].

$\mathrm{y}$ наукових дослідженнях широко представлено тему побудови профрілактично-оздоровчих занять для осіб зрілого віку, в тому числі і жінок другого періоду зрілого віку $[9,16,18]$, розглянуто проблему надлишкової маси тіла [12, 17]. Проте питання вивчення особливостей мотиваційного та психічного станів жінок другого періоду зрілого віку з надлишковою масою тіла залишається відкритим, а проєктування профілактично-оздоровчих занять 3 урахуванням цього фрактора - перспективним для досліджень.

На сьогодні вже ні в кого не викликає сумнівів той факт, що соматичний або фрізіологічний рівень організації людини знаходиться під безпосереднім контролем та впливом психіки [4, 14]. Дослідження особливостей мотиваційного та психічного станів жінок другого періоду зрілого віку з надлишковою масою тіла, на нашу думку, покликане підвищити есрективність побудови самостійних профрілактично-оздоровчих занять.

Дослідження виконано відповідно до плану наукової роботи НУФВСУ на 2016-2020 рр. згідно 3 темою кафедри здоров'я, срітнесу та рекреації «Теоретико-методологічні засади оздоровчо-рекреаційної рухової активності різних груп населення» (номер держреєстрації 0116U001630).

Мета дослідження - вивчити особливості мотиваційного та психічного станів жінок другого періоду зрілого віку з надлишковою масою тіла як основи побудови самостійних профрілактично-оздоровчих занять.

Методи дослідження: теоретичний аналіз та узагальнення сучасних даних наукової, методичної та спеціальної літератури, соціологічні, педагогічні, психодіагностичні методи дослідження [10], методи математичної статистики.

Результати дослідження та їх обговорення. У дослідженні взяли участь 105 жінок другого періоду зрілого віку (середній вік 38,9 року). Для успішної побудови профілактично-оздоровчих занять з використанням інфрормаційних технологій ми дотримувались головного принципу, який базується на індивідуальному підході і передбачає не тільки врахування показників фізичного стану, а й мотиваційні пріоритети жінок другого періоду зрілого віку. Відомо, що ціннісні пріоритети визначають специфріку проблемного поля і суттєво впливають на ефективність занять.

Т а б л и ц я 1. Мотиваційні пріоритети жінок другого періоду зрілого віку до самостійних занять оздоровчим фітнесом $(n=105)$

\begin{tabular}{|c|c|c|}
\hline Фактори & Ранг & $\begin{array}{l}\text { Кількість } \\
\text { жінок, \% }\end{array}$ \\
\hline \multicolumn{3}{|l|}{ Мотиви оздоровлення } \\
\hline $\begin{array}{l}\text { Покращення стану здоров'я, функціональних можливостей } \\
\text { організму }\end{array}$ & 1 & 82,7 \\
\hline Профілактика захворювань, сповільнення інволюційних змін & 2 & 60,9 \\
\hline \multicolumn{3}{|l|}{ Естетичні мотиви } \\
\hline $\begin{array}{l}\text { Підвищення тілесної привабливості (фігура, статура, постава), } \\
\text { корекція маси тіла }\end{array}$ & 3 & 69,5 \\
\hline \multicolumn{3}{|l|}{ Особистісні мотиви } \\
\hline $\begin{array}{l}\text { Підвищення самооцінки, впевненості у собі, нервово-психічної } \\
\text { стійкості до стресових впливів }\end{array}$ & 4 & 49,5 \\
\hline \multicolumn{3}{|l|}{ Рекреаційні мотиви } \\
\hline $\begin{array}{l}\text { Активне дозвілля, емоційно-приваблива організація вільного } \\
\text { часу }\end{array}$ & 5 & 40,9 \\
\hline Задоволення від занять & 6 & 29,5 \\
\hline $\begin{array}{l}\text { Покращення психоемоційного стану (знаття емоційного напру- } \\
\text { ження, покращення настрою) }\end{array}$ & 7 & 24,8 \\
\hline \multicolumn{3}{|l|}{ Пізнавальні мотиви } \\
\hline $\begin{array}{l}\text { Бажання навчитися нового, розвиватись, підвищення рівня } \\
\text { знань }\end{array}$ & 8 & 34,3 \\
\hline $\begin{array}{l}\text { Підвищення та збереження працездатності, професійного } \\
\text { довголіття }\end{array}$ & 9 & 31,4 \\
\hline \multicolumn{3}{|l|}{ Мотиви престижу } \\
\hline Бажання бути модною, не відставати, йти в ногу з часом & 10 & 24,8 \\
\hline Бажання підвищити престиж, бути прийнятою у суспільстві & 11 & 12,4 \\
\hline
\end{tabular}

Жінкам другого періоду зрілого віку було запропоновано обрати чинники, що спонукають їх займатися руховою активністю. В результаті анкетування було визначено п'ять основних груп мотивів (табл. 1).

У переважної більшості жінок другого періоду зрілого віку результати анкетування вказують на те, що 82,7 \% усвідомлюють значущість рухової активності, яка, на їх думку, сприяє покращенню власного стану здоров'я. Для 60,9 \% жінок рухова активність виступає як профілактика захворювань та сповільнення інволюційних змін. Отже, оздоровчі мотиви для цих жінок є найбільш пріоритетними і за рангом посідають перше і друге місця. На третьому місці знаходяться естетичні мотиви, для 69,5\% жінок підвищення тілесної привабли- 
Т а б л и ц я 2. Результати анкетування жінок другого періоду зрілого віку за шкалою оцінки якості життя (SF - 36) в балах, $(\mathrm{n}=105)$

\begin{tabular}{|l|c|c|}
\hline \multicolumn{1}{|c|}{ Критерії якості життя } & x & Рівень \\
\hline Робота & $24,6 \pm 0,97$ & середній \\
\hline Особисті досягнення & $33,1 \pm 1,26$ & високий \\
\hline Здоров'я & $16,4 \pm 0,83$ & низький \\
\hline Спілкування з близькими & $21,6 \pm 0,95$ & низький \\
\hline Підтримка (внутрішня і зовнішня) & $23,7 \pm 1,33$ & середній \\
\hline Оптимізм & $25,3 \pm 2,24$ & середній \\
\hline Напруження & $16,7 \pm 1,64$ & низький \\
\hline Самоконтроль & $28,4 \pm 0,51$ & середній \\
\hline Негативні емоції & $23,2 \pm 2,34$ & середній \\
\hline Їндекс якості життя & $25,7 \pm 1,13$ & середній \\
\hline
\end{tabular}

вості, корекція маси тіла є основним стимулом для занять. Наступним мотиваційним пріоритетом є психологічні мотиви, так, 49,5 \% жінок другого періоду зрілого віку займаються руховою активністю для підвищення самооцінки, впевненості у собі, підвищення нервово-психічної стійкості до стресових впливів. Рекреаційні мотиви для 40,9 \% жінок - це передовсім активне дозвілля та емоційно-приваблива організація вільного часу. Для 29,5 \% жінок рухова активність приносить задоволення, а для 24,8 \% заняття сприяють покращенню психоемоційного стану. Особистісним мотивам надали перевагу 34,3 \% опитаних, які бажають навчитися чогось нового, розвиватись, підвищувати свій рівень знань. На нашу думку, надання переваги особистісним мотивам пов'язане перш за все з можливістю отримання інсормації про раціональну організацію рухової активності, проведення самоконтролю під час самостійних занять, а також отримання знань про раціональне харчування. Для 31,4% жінок другого періоду зрілого віку заняття руховою активністю сприяють підвищенню та збереженню працездатності, а також впливають на продовження професійного довголіття.

Під час вивчення мотиваційних пріоритетів було встановлено, що 24,8 \% жінок займаються руховою активністю, щоб бути модною, а 12,4 \%, щоб підвищити свій престиж і бути прийнятою у суспільство. Слід відмітити, що престижним мотивам надала перевагу найменша кількість жінок.

У своїй роботі ми використовували шкалу оцінювання якості життя. Запропонована методика містить 36 запитань, які стосуються задоволеності в таких категоріях індивідуального життя: робота, особисті досягнення, здоров'я, спілкування з близькими людьми, підтримка (внутрішня і з0внішня - соціальна), оптимістичність, напруженість (фрізичний і психічний дискомфорт), самоконтроль, негативні емоції (настрій). Запропонована методика може виявити сфери життєдіяльності, які викликають найбільший дискомфорт або незадоволеність.

Результати досліджень, які представлено в таблиці 2, вказують на те, що середньогруповий показник індексу якості життя у жінок другого періоду зрілого віку відповідає середньому рівню і становить 25,7 бала. Аналіз індивідуальних результатів дав змогу виявити $17,1 \%$ жінок 3 низьким та 20,0 \% 3 високим індексом якості життя.

Аналіз результатів анкетування за першим блоком, який вказує на професійну діяльність, відповідає середньому рівню і свідчить про задоволення опитуваних жінок другого періоду зрілого віку від роботи, про хороші взаємостосунки 3 колегами та керівництвом, нормальний фрінансовий стан та можливість кар'єрного зростання. Аналіз індивідуальних резуль- татів анкетування за цим блоком виявив 24,8 \% жінок, які були незадоволені своїм фінансовим становищем та відсутністю кар'єрного росту.

Результати другого блоку, що характеризує особисті досягнення, відповідають високому рівню якості життя і характеризують нашу вибірку як жінок, які досягли певних цілей, задоволені собою, дотримуються своїх принципів, отримали визнання та повагу у діловому оточенні.

Аналіз третього блоку показав, що жінки оцінюють власне здоров'я як низький рівень і вказують на часті захворювання, нерегулярну фрізичну активність, поганий сон, а також незадоволення своєю фрізичною формою. Дану особливість можна пояснити негативним впливом надлишкової маси тіла, що суттєво впливає на загальний стан здоров'я.

Четвертий блок, який характеризує спілкування з близькими, в опитаних жінок відповідає низькому рівню зазвичай за рахунок напружених стосунків з дітьми, відсутності щирих стосунків 3 друзями та незадоволеності сексуальним життям.

Аналіз результатів п'ятого блоку, який характеризує підтримку (внутрішню та зовнішню), відповідає середньому рівню якості життя. Опитані жінки вказують на присутність духовної та релігійної підтримки, у переважної більшості з них значна професійна та ділова підтримка та відчуття внутрішнього ресурсу.

Судячи 3 відповідей на шостий блок запитань, який характеризує оптимізм, жінки другого періоду зрілого віку вказують на гарний настрій, вони життєрадісні, хоча часто бувають перепади настрою, у важких життєвих ситуаціях ніколи не втрачають надію. Середньогруповий результат відповідає середньому рівню якості життя.

Результати сьомого блоку, який характеризує напруження, вказують на низький рівень. Жінки скаржаться на постійний брак часу, на небезпечне навколишнє середовище, відчуття постійної втоми та напруження, а також наявність життєвих кризових ситуацій.

Наступний блок характеризує самоконтроль, а отримані відповіді свід- 
чать про середній рівень якості життя. Переважна більшість респондентів володіють собою, легко приймають рішення, беруть на себе відповідальність, але нервують при зміні планів.

Дев'ятий блок характеризує негативні емоції, а отримані відповіді відповідають середньому рівню. У переважної більшості $(70,5$ \%) жінок присутне відчуття вини та сорому, вони часто гніваються на себе, у них присутнє почуття страху та тривоги.

Наступним етапом нашої наукової роботи було визначення психічного стану жінок. Відомо, що психічні стани дуже часто $є$ інсрормативним регулятором поведінки людини, які істотно впливають на настрій, самопочуття та загальний тонус. Виникнення негативних психічних станів найчастіше пов'язане з несприятливими умовами і стресовими ситуаціями, які можуть проявлятися в умовах внутрішнього дискомфорту при зміні звичного способу життя. Так, негативний емоційний стан є фрактором ризику для виникнення гострого дискомфортного стану психіки. 3 наукових джерел відомо, що наявні психоемоційні порушення є одними із чинників, які призводять до ожиріння.

У нашому дослідженні ми використовувати тест Г. Айзенка, за допомогою якого можна самостійно визначити рівні таких психічних станів, як тривожність, фррустрація, агресивність, ригідність. Згідно із запропонованою методикою, тривожність пов'язана з очікуванням неблагополуччя та розглядається як показник емоційного дискомфорту. Показник фррустрації розглядається як психічний стан, викликаний незадоволеністю бажань та потреб, часто проявляється в негативних переживаннях: розчарування, роздратування, тривога, розпач. Показник ригідності вказує на нездатність проявляти пластичність у своїх переживаннях, установках, поведінці. Агресивність розглядається як неспровокована ворожість людини по відношенню до інших людей і оточуючого світу.

Аналіз індивідуальних результатів, отриманих у ході тестування психічних станів жінок, вказують на низький та середній рівні тривожності, фрр- страції, агресивності та ригідності. Середньогруповий показник тривожності у жінок другого зрілого віку відповідає середньому рівню. Найбільше балів отримали стани, які часто зустрічаються і стосуються уявних неприємностей, неспокійного сну. Жінки також вказували на те, що вони важко переносять час очікування. Серед обстежених жінок 82,9 \% мали середній рівень тривожності, 17,1 \% - низький

Аналіз середньогрупового показника фррустрації у жінок другого зрілого віку відповідає середньому рівню. Переважна більшість опитаних вказували на те, що «Неприємності мене сильно засмучують» та «У важкі хвилини життя іноді поводжуся, як дитина, хочу щоб пожаліли» виникають у них часто. В ході аналізу отриманих результатів ми встановили, що 70,5 \% жінок мають середній рівень фррустрації, 29,5 \% - низький.

Середньогруповий показник агресивності у жінок другого зрілого віку відповідає середньому рівню. Переважна більшість іспитованих вказували, що стани «Коли розгніваюсь, погано себе стримую» та «Волію краще керувати ніж підкорятися» зустрічаються у них часто. Ми встановили, що 60,9 \% жінок мають середній рівень агресивності, 39,1 \% - низький.

Результати показника ригідності у жінок другого зрілого віку розподілилися таким чином: низький рівень мають 30,5\%; середній 69,5\%. У жінок найчастіше збігалися описані стани «Мені важко змінювати звички», «Неохоче йду на ризик», «Часто в мене не виходить 3 голови думка, якої слід було б позбутися».

Висновки. Отримані результати дали змогу виділити проблемні сфери життєдіяльності у жінок другого періоду зрілого віку з надлишковою масою тіла та встановити чинники, які викликають дискомфорт та незадоволеність якістю життя. Основною проблемою є низький рівень здоров'я, наявність стресових ситуацій та постійної втоми і все це на фоні дефіциту часу. У багатьох жінок напружені стосунки 3 дітьми, що негативно впливає на їхній емоційний стан і може бути причиною поганого сну, відчуття вини, незадоволеність собою, хоча їхні особис- ті досягнення відповідають високому рівню і вказують на професійну реалізованість, фрінансову стабільність, повагу та підтримку колег. Результати дослідження особливостей психічних станів у жінок другого періоду зрілого віку 3 надлишковою масою тіла вказують на відсутність високого рівня тривожності, фррустрації, агресивності та ригідності. Зазначені особливості будуть покладені в основу розробки програми самостійних занять оздоровчим фрітнесом з використанням інформаційних технологій.

Перспективи подальших досліджень полягають у використанні отриманих результатів під час обґрунтування та розробки програми самостійних профілактично-оздоровчих занять для жінок другого періоду зрілого віку з надлишковою масою тіла.

Конфлікт інтересів. Автори заявляють, що відсутній будь-який конфлікт інтересів.

\section{ЛITEPATУРA}

1. Андреева ЕВ, Садовский АА. Система ценностных ориентаций как основа формирования рекреационной культуры студентов. Теория и методика фризической культуры. 2015; (2): 51-9.

2. Андрєєва О. Соціально-психологічні чинники, що детермінують рекреаційно-оздоровчу активність осіб різного віку. Теорія і методика фрізичного виховання і спорту. 2014; 3(106): 25-31.

3. Андрєєва ОВ. Розробка та впровадження технології проектування активної рекреаційної діяльності різних груп населення. Спортивний вісник Придніпров'я. 2015; (1): 4-9.

4. Апанасенко ГЛ. Валеология или Медецина 4Р? Как избежать инфаркта, инсульта и диабета. 2020. 144.

5. Беляк ЮІ. Спосіб інтегральної оцінки фізичного фітнесу жінок зрілого віку. Фізичне виховання, спорт і культура здоров'я у сучасному суспільств. 2012; (4): 244-7.

6. Беляк Ю, Майструк А, Зінченко Н. Характеристика сучасних програм оздоровчого фітнесу. Педагогіка, психологія та медикобіологічні проблеми фізичної культури і спорту [Інтернет]. 2006 [Цитовано 2020 Трав. 22] 4: 14-16 Доступно: https://www.sportpedagogy. org.ua/html/Pedagogy/Pdf2006/PD-2006-04 pdf\#page $=15$

7. Беставишвили ТГ. Разумный фритнес. Книга руководителя. Санкт-Петербург: НесторИстория. 2011: 536.

8. Благій ОЛ, Андрєєва ОВ. Рухова активність як фактор формування здорового способу життя учнівської молоді. Актуальн проблеми фрізичного виховання, реабілітації, спорту та туризму. 2011: 27-8.

9. Жигалова ЯВ. Проектирование комплексных оздоровительных фиитнес-программ для женщин 30-50-летнего возраста [авторе- 
ферат]. Москва: Московский городской педагогический институт; 2003: 23.

10. Заика EB, Зимовин АИ. Методики исследования эмоциональной сферы человека учебно-методическое пособие. 2018: 260.

11. Круцевич Т, Имас Т. Ценностные ориентации лиц зрелого возраста в проведении досуга. Спортивний вісник Придніпров'я. 2012;(2): $5-12$

12. Мороз ЕА. Коррекция массы тела женщин 21-35 лет средствами оздоровительного фитнеса. [автореферат]. Киев. 2011: 19.

13. Ріпак МЯ. Організаційно-методичн аспекти оптимізації фрізичної активності жінокучителів 36-55 років [автореферат]. Львів: Львівський державний інститут фрізичної культури. 2006. 23

14. Столяренко ОБ. Психологія особистості: навчальний посібник. Київ: Центр учбової літератури. 2012. 280.

15. Andrieieva 0. Hakman A., Kashuba V Vasylenko M, Patsaliuk K, Koshura A \& Istyniuk I. (2019). Effects of physical activity on aging processes in elderly persons. Journal of Physical Education and Sport, 20(3), 1308-1314. https://doi. org/10.7752/jpes.2019.s4190

16. Drozdovska S, Andrieieva 0, Yarmak 0 \& Blagii 0. (2020). Personalization of health-promoting fitness programs for young women based on genetic factors. Journal of Physical Education and Sport, 20(S1), 331-337. DOI: 10.7752/jpes.2020. s1046

17. Lazareva 0, Aravitska M, Andrieieva 0 Galan Y \& Dotsyuk L. (2017). Dynamics of physical activity status in patients with grade I-III obesity in response to a physical rehabilitation program.
Journal of Physical Education and Sport, 17(3) 1960-1965. DOI: 10.7752/jpes.2017.03193

18. Mazur II, Drozdovska S, Andrieieva 0, Vinnichuk Y, Polishchuk A, Dosenko V, ... Ahmetov II. (2020). PPARGC1A gene polymorphism is asso ciated with exercise-induced fat loss. Molecula Biology Reports. https://doi.org/10.1007/s11033020-05801-z

\section{LITERATURE}

1. Andreieva EV, Sadovsky AA. The system of value orientations as the basis for the formation of students' recreational culture.Teoriya i metodika fizkultury. 2015; (2): 51-9.

2. Andreieva 0. Sociopsychological factor determining recreational and health related activity of persons of different age. Teoriia i metodyka fizvykhovannia i sportu. 2014; 3(106): 25-31.

3. Andreieva OV. Development and implementation of the technology for projecting active recreational activity of different population groups. Sportyvnyi visnyk Prydniprovia. 2015; (1): 4-9.

4. Apanasenko GL. Valeology or Medicine 4P? How to avoid heart attack, stroke and diabetes. 2020. 144

5. Beliak II. Method of integral assessment of mature women's physical fitness. Fizychne vyk hovannia, sport i kultura zdorovia u suchasnomu suspilstvi. 2012; (4): 244-7

6. Beliak I, Maystruk A, Zinchenko N. Characteristics of modern health fitness programs. Pedahohika, psykholohiia ta medyko-biolohichni problem fizychnoho vykhovannia i sportu [Internet] 2006 [Cited 2020 May 22]; 4: 14-16 Avai-

\section{ІНФОРМАЦІЯ ПРО АВТОРІВ}

Нагорна Анастасія Юріївна https://orcid.org/0000-0003-3286-9299, info@fitnessathome.com.ua Андрєєва Олена Валеріївна https://orcid.org/0000-0002-2893-1224, olena.andreeva@gmail.com Левінська Ксенія Ігорівна https://orcid.org/0000-0002-8206-6745, andreeva.ksjusha@gmail. com

Національний університет фізичного виховання і спорту України 03150, Київ, вул. Фізкультури, 1

\section{INFORMATION ABOUT THE AUTHORS}

Nahorna Anastasiia https://orcid.org/0000-0003-3286-9299, info@fitnessathome.com.ua Andrieieva Olena https://orcid.org/0000-0002-2893-1224, olena.andreeva@gmail.com Levinska Ksenia https://orcid.org/0000-0002-8206-6745, andreeva.ksjusha@gmail.com National University of Ukraine on Physical Education and Sport 03150, Kyiv, Fizkul'tury str., 1. lable: https://www.sportpedagogy.org.ua/html/ Pedagogy/Pdf2006/PD-2006-04.pdf\#page=15

7. Bestavishvili TG. Clever fitness. Head's book. St. Petersburg: Nestor-Istoriya. 2011: 536.

8. Blahii OL, Andreieva OV. Motor activity as a factor of healthy ;ife style formation in student youth. Aktualni problem fizvykhovannia, reabilitatsii, sportu ta turyzmu. 2011: 27-8.

9. Zhigalova YV. Projecting complex health related fitness programs for women aged 30-50 [author's abstract]. Moscow: Moskovsky gorodskoy peinstitut; 2003: 23

10. Zaika EV, Zimovin Al. Methods of studying human emotional sphere: instructional guide. 2018: 260 .

11. Krutsevich T, Imas T. Value orientations of mature age persons with respect to leisure activities. Sportyvnyi visnyk Prydniprovia. 2012;(2): 5-12.

12. Moroz EA. Correcting body mass of women aged $21-35$ by health fitness means. [author's abstract]. Kiev. 2011: 19.

13. Ripak MI. Organizational and methodical aspects of optimizing physical activity of female teachers aged 36-55 [author's abstract]. Lviv: Lvivskyi derzhavnyi instytut fizkultury. 2006. 23.

14. Stoliarenko OB. Psychology of personality: teaching guide. Kyiv: Tsentr uchbovoi literatury. 2012. 280.

15. Andrieieva 0. Hakman A., Kashuba V, Vasylenko M, Patsaliuk K, Koshura A \& Istyniuk I. (2019). Effects of physical activity on aging processes in elderly persons. Journal of Physical Education and Sport, 20(3), 1308-1314. https://doi. org/10.7752/jpes.2019.s4190

16. Drozdovska S, Andrieieva O, Yarmak 0 \& Blagii 0. (2020). Personalization of health-promoting fitness programs for young women based on genetic factors. Journal of Physical Education and Sport, 20(S1), 331-337. DOI: 10.7752/jpes.2020. s1046

17. Lazareva O, Aravitska M, Andrieieva O, Galan Y \& Dotsyuk L. (2017). Dynamics of physical activity status in patients with grade I-III obesity in response to a physical rehabilitation program. Journal of Physical Education and Sport, 17(3), 1960-1965. DOI: 10.7752/jpes.2017.03193

18. Mazur II, Drozdovska S, Andrieieva O, Vinnichuk Y, Polishchuk A, Dosenko V, ... Ahmetov II. (2020). PPARGC1A gene polymorphism is associated with exercise-induced fat loss. Molecular Biology Reports. https://doi.org/10.1007/s11033020-05801-z 